\title{
MADRASAH
}

Jurnal Pendidikan dan Pembelajaran Dasar

$P$ a g e $\mid \mathbf{2 0}$

p ISSN: 1979-5599 | e ISSN: 2502-194X

\section{MENANAMKAN KARAKTER RELIGIUS SISWA MELALUI BUKU AJAR TEMATIK TERINTEGRASI PAI DAN BUDI PEKERTI}

\author{
Sulistyowati \\ Institut Agama Islam Negeri Palangka Raya, Indonesia \\ liezz.sulis@gmail.com
}

\begin{abstract}
Textbook is one of learning components that plays an important role in determining the success of learning. Textbook as a media and one of main resources in the learning process has a strategic role to be developed to improve the quality of learning and cultivate religiosity of the students. The cultivation of religious characters will be effective, efficient, and interesting if the available textbooks are combined with the Islamic education and characters contents. Those contents will create religious atmosphere and familiarize the students in practising their religiosity in everyday life. In this way, the competency of Islamic education and characters are combined with the competency of other subjects that are packaged in a learning experience. Thus the Islamic values will be formed in students characters.
\end{abstract}

Keyword: Religious Character; Thematic Textbook; Integrated; Islamic Education; Characters

Copyright (C) 2017 Madrasah Jurnal Pendidikan dan Pembelajaran Dasar. All Right Reserved

\section{A. PENDAHULUAN}

Model pendidikan selalu berkembang sesuai dengan tuntutan zaman. Hal ini sejalan dengan kebutuhan masyarakat yang menginginkan model pendidikan yang mampu menjawab persoalan mereka. Kehadiran kurikulum 2013 yang merupakan penyempurnaan dari kurikulum sebelumnya perlu ditindaklanjuti demi tercapainya tujuan pendidikan yang ditetapkan. Kurikulum 2013 menekankan pada terbentuk dan berkembangnya sikap siswa, termasuk sikap spiritual. Sikap spiritual yang ditanamkan pada diri peserta didik akan tumbuh menjadi karakter religius yang melekat pada dirinya.

Selama ini saat mengamati kegiatan belajar mengajar di Sekolah Dasar/Madrasah Ibtidaiyah, materi dan nilai pendidikan karakter cenderung hanya diajarkan pada saat pelajaran pendidikan agama islam dan budi pekerti sehingga mereduksi aplikasinya hanya sebatas pada ranah etika. Padahal, konsep pendidikan karakter menuntut penjabaran lebih komprehensif, sehingga tidak hanya berbicara jauh pada tataran teoritis, tapi lemah dalam penjabaran implementasi dalam kehidupan sehari-hari. Proses penanaman karakter tidak selayaknya diajarkan dengan cara yang sempit. Sebab, hal itu akan menjadikan siswa mempunyai kecenderungan berpikir yang sempit pula. Menurut $\mathrm{Mu}^{\prime}$ in, penanaman karakter dalam konsep agama tidak melihat bahwa karakter yang ada pada diri siswa adalah produk dialektika dengan pengalaman historisnya dan

Vol. 10 No. 1, Desember 2017

Madrasah homepage: http://ejournal.uin-malang.ac.id/index.php/madrasah/index 


\section{MADRASAH}

Jurnal Pendidikan dan Pembelajaran Dasar

p ISSN: 1979-5599 | e ISSN: 2502-194X

P a g e

sejarah hubungannya dengan orang lain. Keberagamaan yang dialami oleh siswa tersebut hanya akan menghasilkan sosok yang mengetahui "halal" dan "haram" berdasarkan teks yang ditafsirkan secara saklek dan diseleksi atau ditafsirkan sesuai kepentingan tertentu (Fatchul Mu'in, 2011:316-317).

Proses penanaman nilai-nilai atau karakter melalui beberapa tahapan. Mengacu pada teori yang dikembangkan oleh Muhaimin, proses penanaman nilainilai atau karakter melalui tahapan sebagai berikut. Pertama, transformasi nilai. Tahap ini merupakan suatu proses yang dilaksanakan oleh guru dalam menginformasikan nilai-nilai pendidikan karakter. Pada tahap ini, hanya terjadi komunikasi verbal antara guru dan siswa. kedua, tahap transaksi nilai. Pada tahap ini pendidikan karakter disajikan dengan jalan melakukan komunikasi dua arah atau interaksi antara siswa dnegan guru yang bersifat interaksi timbal-balik. Ketiga, tahap transinternalisasi. Tahap ini jauh lebih mendalam dari tahap transaksi. Pada tahap ini bukan hanya dilakukan dengan komunikasi verbal, melainkan juga sikap mental dan kepribadian ke dalam diri siswa. jadi, pada tahap ini komunikasi kepribadian yang dijalankan guru kepada siswa lebih dominan dan berperan secara aktif (Muhaimin, 1996:153).

Salah satu indikator utama dari kurang berhasilnya pendidikan agama dalam menanamkan dan membentuk karakter religius siswa adalah masih banyaknya siswa yang terlibat kekerasan, pencurian, dan penyalahgunaan obatobatan terlarang, dalam hal ini tidak menutup kemungkinan pelakunya adalah anak usia sekolah dasar/madrasah ibtidaiyah. Berdasarkan berbagai hasil penelitian tentang problematika pembelajaran Pendidikan Agama Islam selama ini, salah satu faktor yang mempengaruhi adalah karena pelaksanaan pembelajaran Pendidikan Agama Islam cenderung bersifat kognitif, tidak sampai pada pembentukan karakter religius pada siswa. selain itu, secara gamblang Asmaun menjelaskan beberapa latar belakang munculnya kekurangberhasilan Pendidikan Agama Islam dalam menanamkan karakter sebagaimana berikut. Pertama, keterbatasan alokasi waktu. Kedua, strategi pembelajaran yang berorientasi pada aspek kognitif. Ketiga, proses pembelajaran cenderung pada transfer of knowledge, bukan internalisasi atau penanaman nilai atau karakter. Keempat, pengaruh negatif dari lingkungan dan teknologi informasi. Oleh sebab itu, tawaran yang disajikan sebagai upaya mewujudkan Pendidikan Agama Islam yang menekankan pada penanaman karakter religius adalah dengan penambahan jam pelajaran, peningkatan kualitas pembelajaran, pengembangan melalui kegiatan ekstrakurikuler, dan pembudayaan nilai-nilai religius di sekolah (Asmaun Sahlan, 2009:93-113).

Selain beberapa tawaran di atas, penanaman karakter religius pada siswa juga bisa melalui pengintegrasian mata pelajaran PAI dan Budi Pekerti dengan mata pelajaran umum atau tematik pada Sekolah Dasar/Madrasah Ibtidaiyah. Hal ini sejalan dengan cita-cita integrasi sains dan Islam dalam rangka mempersempit jurang pemisah antara keduanya. Dengan adanya integrasi, maka siswa akan

Vol. 10 No. 1, Desember 2017

Madrasah homepage: http://ejournal.uin-malang.ac.id/index.php/madrasah/index 
mendapatkan pengatahuan yang utuh ketika mempelajari suatu ilmu. Hal ini senada dengan pola perkembangan pemikiran siswa usia sekolah dasar/madrasah ibtidaiyah di mana siswa masuk pada rentangan usia dini. Pada usia tersebut seluruh aspek perkembangan kecerdasan seperti IQ, EQ, dan SQ tumbuh dan berkembang sangat luar biasa. Pada umumnya mereka masih melihat segala sesuatu sebagai satu keutuhan (berpikir holistik) dan memahami hubungan antara konsep secara sederhana. Proses pembelajaran masih bergantung pada objek-objek konkret dan pengalaman yang dialami secara langsung (F.J. Monks, A.M.P., 2004: 21).

Tawaran di atas menjadi hal yang menarik yang bisa dikembangkan oleh guru sebagai pelaksana pembelajaran yaitu dengan meningkatkan kualitas pembelajaran melalui dukungan buku ajar yang digunakan dalam pembelajaran, yakni buku ajar tematik terintegrasi PAI dan Budi Pekerti. Mengingat buku ajar yang diterbitkan oleh pemerintah (kementrian pendidikan dan kebudayaan) dalam paket kurikulum 2013 masih terpisah antara buku ajar tematik dan buku ajar PAI dan Budi Pekerti baik buku guru maupun buku siswa. Buku ajar merupakan salah satu jenis buku pendidikan. Buku ajar adalah buku yang berisi uraian bahan tentang mata pelajaran atau bidang studi tertentu, yang disusun secara sistematis dan telah diseleksi berdasarkan tujuan tertentu, orientasi pembelajaran, dan perkembangan siswa, untuk diasimilasikan. Buku ajar adalah buku yang digunakan sebagai buku pelajaran dalam bidang studi tertentu, yang merupakan buku standar yang disusun oleh pakar dalam bidangnya untuk maksud-maksud dan tujuan instruksional, yang dilengkapi dengan sarana-sarana pengajaran yang serasi dan mudah dipahami oleh para pemakainya disekolah-sekolah dan perguruan tinggi sehingga dapat menunjang suatu progam pengajaran. Buku ajar merupakan salah satu sarana keberhasilan proses belajar mengajar. Buku ajar merupakan suatu kesatuan unit pembelajaran yang berisi informasi, pembahasan serta evaluasi. Buku ajar yang tersusun secara sistematis akan mempermudah peserta didik dalam materi sehin-gga mendukung ketercapaian tujuan pembelajaran. Maka dari itu, buku ajar harus disusun secara sistematis, menarik, aspek keterbacaan tinggi, mudah dicerna, dan mematuhi aturan penulisan yang berlaku.

Buku ajar tematik terintegrasi PAI dan Budi Pekerti adalah sebuah buku ajar yang berisi muatan kompetensi dasar dari berbagai mata pelajaran, termasuk PAI dan Budi Pekerti yang dikemas dan dipadukan dalam satu tema yang relevan sebagai topik inti. Buku ajar tematik terintegrasi PAI dan Budi Pekerti dipilih sebagai sarana untuk menanamkan karakter religius pada siswa juga karena posisi strategis buku ajar pada kurikulum 2013. Buku ajar merupakan media utama dalam melaksanakan pembelajaran di kelas. Dengan adanya perpaduan atau integrasi antara tematik dan PAI dan Budi Pekerti, diharapkan penanaman karakter religius pada siswa lebih efektif, efisien, dan menarik.

\section{B. PEMBAHASAN}

\section{Karakter Religius}

Karakter religius terdiri dari kata karakter dan religius. Ditinjau dari sisi bahasa, karakter berasal dari bahasa Latin character, yang berarti watak, tabiat, sifat-

Vol. 10 No. 1, Desember 2017

Madrasah homepage: http://ejournal.uin-malang.ac.id/index.php/madrasah/index 


\section{MADRASAH}

Jurnal Pendidikan dan Pembelajaran Dasar

p ISSN: 1979-5599 | e ISSN: 2502-194X

P a g e

sifat kejiwaan, budi pekerti, kepribadian dan akhlak. Istilah karakter juga diadopsi dari bahasa Latin kharakter, kharessian, dan xharaz yang berarti tool for marking, to engrave, dan pointed stake (Wyne dalam Musfah, 2011:127). Dalam bahasa Inggris diterjemahkan menjadi character. Character berarti tabiat, budi pekerti, watak (John Echols, 2005:37). Dalam bahasa Arab, karakter diartikan 'khuluq, sajiyyah, thab'u' (budi pekerti, tabiat atau watak). Kadang juga diartikan syakhsiyyah yang artinya lebih dekat dengan personality (kepribadian) (Aisyah Boang dalam Supiana, 2011: 5). Karakter adalah niali-nilai perilaku manusia yang berhubungan dengan Tuhan Yang Maha Esa, diri sendiri, sesama manusia, lingkungan, dan kebangsaan, yang terwujud dalam pikiran, sikap, perasaan, perkataan, dan perbuatan berdasarkan norma-norma agama, hukum, tata krama, budaya, dan adat istiadat. Karakter dimaknai sebagai cara berpikir dan berperilaku yang khas tiap individu untuk hidup dan bekerja sama, baik dalam lingkup keluarga, masyarakat, bangsa, dan negara. Karakter bisa juga dimaknai seabagai nilai dasar yang membangun pribadi seseorang, terbentuk baik karena pengaruh hereditas maupun pengaruh lingkungan, yang membedakannya dengan orang lain, serta diwujudkan dalam sikap dan perilakunya dalam kehidupan sehari-hari.

Religius berasal dari kata dasar religi yang berasal dari dari bahasa Latin religio yang memiliki akar kata religare yang berarti meningkat. Sehingga tak mengherankan jika di dalam religi (agama) banyak terdapat aturan-aturan dan kewajiban-kewajiban yang harus dilaksanakan, yang berfungsi untuk mengikat diri seseorang atau kelompok orang dalam hubungan dengan Tuhan, sesama manusia serta alam sekitarnya (Dwi Yuliyanti Astuti, 1974:41). Religius bisa juga diartikan bersifat religi atau bersifat keagamaan. Religius adalah sikap seseorang yang berhubungan dengan agamanya. Nilai religius adalah nilai-nilai kehidupan yang mencerminkan tumbuhkembangnya kehidupan beragama yang terdiri dari tiga unsur pokok, yaitu aqidah, ibadah, dan akhlak yang menjadi pedoman perilaku sesuai dengan aturanaturan ilahi untuk mencapai kesejahteraan serta kebahagiaan hidup di dunia dan akhirat. Sikap religius yag tampak pada diri seseorang ketika menjalankan tugasnya antara lain seperti jujur, adil, bermanfaat bagi orang lain, rendah hati, bekerja efisien, mempunyai visi ke depan, disiplin tinggi, dan seimbang dalam menjalani hidup (Asmaun Sahlan, 2009: 67-68). Religius dimaknai juga sebagai ketaatan dan kepatuhan dalam memahami dan melaksanakan ajaran agama yang dianut, termasuk dalam hal ini adalah sikaptoleran terhadap pelaksanaan ibadah agama lain, serta hidup rukun dan berdampingan.

Siswa yang mempunyai karakter religius berarti siswa yang pada dirinya melekat nilai-nilai keagaman yang ia amalkan dalam kehidupan sehari-hari. Untuk mendukung keberhasilan penanaman karakter religius pada diri siswa, perlu diberikan indikator-indikator pencapaian guna mengukur tingkat keberhasilan penanaman karakter religius tersebut. Adapun beberapa indikator karakter religius yang bisa dinilai dari diri siswa adalah: 1) terbiasa mengucap salam; 2) terbiasa berdoa sebelum dan sesudah belajar; 3) melaksanakan ibadah keagamaan; dan 4) merayakan hari besar keagamaan. Indikator-indikator ini bisa dijadikan pijakan bagi guru dalam mengukur

Vol. 10 No. 1, Desember 2017

Madrasah homepage: http://ejournal.uin-malang.ac.id/index.php/madrasah/index 
karakter religius siswa (Agus Zaenul Fitri, 2012:40). Namun, seyogyanya karakter religius yang ditanamkan pada diri siswa tidak terbatas pada indikator tersebut. Penanaman karakter bisa diperluas maknanya seperti mengenalkan dan membisakan anak meneladani sifat-sifat Rasulullah melalui kisah yang berkaitan dengan materi yang diajarkan.

\section{Buku Ajar Tematik}

Dilihat dari sudut teknologi pendidikan, sumber belajar merupakan segala sesuatu yang mengandung informasi dan dapat dijadikan sebagaibahan belajar yang meliputi pesan, orang, bahan, alat, prosedur/metode/teknik, dan lingkungan. Bahan terdiri atas segala media yang mengandung informasi yang dapat dijadikan sebagai acuan untuk belajar, termasuk buku (B.P. Sitepu, 2012:1819). Secara umum buku mengandung informasi tentang perasaan, pikiran, gagasan, atau pengetahuan pengarangnya untuk disampaikan kepada orang lain dengan menggunakan simbol-simbol visual dalam bentuk huruf, gambar, atau bentuk lainnya. Fungsi utama buku adalah sebagai media informasi yang pada awalnya dalam bentuk tulisan tangan, kemudian cetakan, dan belakangan ini dalam bentuk elektronik.

Buku berfungsi sebagai pedoman manual bagi siswa dalam belajar dan bagi guru dalam membelajarkan siswa. sebagai pedoman belajar bagi siswa, berarti siswa menggunakannya sebagai acuan utama dalam: 1) mempersiapkan diri secara individu atau kelompok sebelum kegiatan belajar di kelas; 2) berinteraksi dalam proses pembelajaran di kelas; 3) mengerjakan tugas-tugas yang diberikan guru; dan 4) mempersiapkan diri untuk tes atau ujian formatif dan sumatif. Bagi guru, buku digunakan sebagai acuan dalam: 1) membuat desain pembelajaran; 2) mempersiapkan sumber-sumber belajar lain; 3) mengembangkan bahan belajar yang kontekstual; 4) memberikan tugas; dan 5) menyusun bahan evaluasi (B.P. Sitepu, 2012:21). Berdasarkan fungsi-fungsi tersebut, muatan yang ada dalam sebuah buku dapat dikembangkan oleh guru sesuai dengan kondisi dan keperluan yang ada, misal dikembangkan dengan memberikan muatan karakter dalam rangka menanamkan karakter pada diri siswa.

Buku ajar adalah buku teks yang digunakan sebagai rujukan standar pada mata pelajaran tertentu. Buku ajar mempunyai beberapa ciri, yaitu: 1) sebagai sumber materi ajar; 2) menjadi referensi baku untuk mata pelajaran tertentu; 3) disusun sistematis dan sederhana; dan 4) disertai dengan petunjuk pembelajaran. Buku ajar yang baik harus memenuhi beberapa kriteria seperti akurat, relevan, komunikatif, lengkap dan sistematis, berorientasi pada siswa, berpihak pada ideologi bangsa dan negara, mempunyai kaidah bahasa yang benar serta mudah terbaca (Sa'dun Akbar, 2013:34-36). Selain itu, ada sepuluh kategori yang harus dipenuhi agar buku ajar berkualitas, diantaranya: 1) buku ajar haruslah menarik minat siswa yang mempergunakannya; 2) buku ajar haruslah mampu memberikan motivasi kepada para siswa yang memakainya; 3) buku ajar haruslah memuat ilustrasi yang menarik siswa yang memanfaatkannya; 4) buku ajar seyogyanya mempertimbangkan aspek-aspek linguistik sehingga sesuai dengan kemampuan

Vol. 10 No. 1, Desember 2017

Madrasah homepage: http://ejournal.uin-malang.ac.id/index.php/madrasah/index 


\section{MADRASAH}

Jurnal Pendidikan dan Pembelajaran Dasar

p ISSN: 1979-5599 | e ISSN: 2502-194X

P a g e

para siswa yang memakainya; 5) isi buku ajar haruslah berhubungan erat dengan pelajaran-pelajaran lainnya, lebih baik lagi kalau dapat menunjangnya dengan terencana sehingga semuanya merupakan suatu kebulatan yang utuh dan terpadu; 6) buku ajar haruslah dapat menstimuli, merangsang aktivitas-aktivitas pribadi para siswa yang mempergunakannya; 7) buku ajar haruslah dengan sadar dan tegas menghindar dari konsep-konsep yang samar-samar dan tidak biasa, agar tidak membuat bingung siswa yang memakainya; 8) buku ajar haruslah mempunyai sudut pandang atau "point of view" yang jelas dan tegas sehingga ada akhirnya juga menjadi sudut pandang para pemakainya yang setia; 9) buku ajar haruslah mamu memberi pemantapan, penekanan pada nilai-nilai anak dan orang dewasa; dan 10) buku ajar haruslah dapat menghargai perbedaan-perbedaan pribadi para pemakainya (Tarigan, 1986:21).

Keakuratan dapat dilihat dari aspek kecermatan penyajian, benar memaparkan hasil penelitian, dan tidak salah mengutip pendapat pakar. Akurasi dapat pula dilihat dari teori perkembangan yang mutakhir dan pendekatan keilmuan yang bersangkutan. Buku ajar yang baik memiliki kesesuaian antara kompetensi yang harus dikuasai dengan cakupan isi, kedalaman pembahasan, dan kompetensi pembaca. Relevansi hendaknya juga menggambarkan kesesuaian antara materi, tugas, latihan, contoh, ilustrasi, dan lain sebagainya dengan kompetensi yang harus dikuasai oleh pembaca sesuai tingkat perkembangan pembacanya. Komunikatif bisa diartikan bahwa isi buku yang disajikan mudah dicerna pembaca, sistematis, jelas, dan tidak mengandung kesalahan bahasa. Penulis menganggap bahwa ia sedang mengajar melalui tulisan.

Buku ajar yang baik menyebutkan kompetensi yang harus dikuasai pembaca, memberikan manfaat pentingnya penguasaan kompetensi bagi kehidupan pembaca, menyajikan daftar isi dan daftar pustaka. Uraian materinya sistematis, mengikuti alur piker dari sederhana ke kompleks, dari lokal ke global. Pendidikan dengan kurikulum yang cenderung konstruktivistik membutuhkan buku ajar yang mendorong rasa ingin tahu siswa, terjadinya interaksi antara siswa dengan sumber belajar, merangsang siswa membangun pengetahuan sendiri, menyemangati siswa belajar secara berkelompok, dan menggiatkan siswa mengamalkan isi bacaan.

Untuk keperluan pendidikan Indonesia, buku ajar yang baik adalah buku ajar yang harus mendukung ketakwaan kepada Tuhan yang Maha Esa; mendukung pertumbuhan nilai kemnausiaan; mendukung kesadaran akan kemajemukan masyarakat; mendukung tumbuhnya rasa nasionalisme; mendukung tumbuhnya kesadaran hukum, dan mendukung cara berpikir logis. Buku ajar yang ditulis menggunakan ejaan, istilah, dan struktur kalimat yang tepat. Buku ajar yang keterbacaannya tinggi mengandung panjang kalimat dan struktur kalimat sesuai dengan pemahaman pembaca, panjang alineanya sesuai pemahaman pembaca. Buku Ajar adalah buku yang digunakan sebagai sumber belajar siswa dalam proses pembelajaran. Buku ajar adalah buku acuan yang digunakan di satuan pendidikan

Vol. 10 No. 1, Desember 2017

Madrasah homepage: http://ejournal.uin-malang.ac.id/index.php/madrasah/index 
yang memuat materi pembelajaran dalam rangka peningkatan keimanan, ketakwaan, akhlak mulia, dan kepribadian, penguasaan ilmu pengetahuan dan teknologi, peningkatan kepekaan dan kemampuan estetis, peningkatan kemampuan kinestetis dan kesehatan yang disusun berdasarkan standar nasional pendidikan.

Buku ajar yang digunakan dalam proses pembelajaran kurikulum 2013 adalah buku ajar tematik. Buku ajar tematik merupakan buku yang digunakan sebagai rujukan atau sumber belajar siswa ketika proses pembelajaran berlangsung. Buku ini memuat tema-tema tertentu yang terbagi dalam beberapa subtema dan dijabarkan dalam bentuk kegiatan pembelajaran pada setiap pertemuannya. Buku ajar tematik adalah buku ajar yang disusun secara sistematis yang memuat kompetensi-kompetensi yang akan dikuasai siswa melalui proses pembelajaran yang mendorong keterlibatan siswa secara aktif dan menyenangkan, yakni tidak semata-mata mendorong siswa untuk mengetahui (learning to know), tetapi juga melakukan (learning to do), menjadi (learning to be), dan hidup bersama (learning to live together), serta holistik dan autentik. Buku ajar tematik disusun secara sistematis dengan melakukan pemetaan kompetensi dan indikator pencapaian pembelajaran dari masing-masing mata pelajaran untuk dipadukan dan disatukan dalam ikatan topik atau tema tertentu. Dalam buku ajar tematik tidak tampak lagi mana mata pelajaran matematika, IPA, IPS, dan mata pelajaran yang lainnya. Pengetahuan yang disajikan berusaha menggiring siswa berpikir secara holistik tanpa memisahmisahkan ilmu dasarnya.

\section{Buku Ajar Tematik Terintegrasi PAI dan Budi Pekerti}

Berdasarkan Peraturan Menteri Pendidikan dan Kebudayaan Republik Indonesia Nomor 71 Tentang Buku Teks Pelajaran dan Buku Panduan Guru untuk Pendidikan Dasar dan Menengah disebutkan bahwa buku teks pelajaran yang digunakan di jenjang pendidikan dasar (MI/SD) adalah buku teks Pendidikan Agama Islam dan Budi Pekerti dan buku teks tematik. Berdasarkan dua buku ini, terlihat bahwa seakan-akan ada pemisahan antara pengetahuan umum dengan agama. Padahal keduanya dapat disandingkan untuk membiasakan siswa sejak usai dini tidak mendikotomikan ilmu pengetahuan, karena pada dasarnya mereka adalah satu kesatuan.

Fenomena yang banyak muncul akhir-akhir ini adalah integrasi sains dan agama. Mulai muncul sebuah kesadaran bahwa perlu adanya integrasi paradigmatik khususnya antara ilmu agama dengan umum. Dalam Islam, aqidah atau keimanan kepada Allah SWT merupakan pandangan hidup bagi setiap muslim dalam menjalani kehidupan. Aqidah mempunyai peranan penting dalam kehidupan umat muslim. Islam memerintahkan manusia untuk membangun segala pemikirannya berdasarkan aqidah Islam. Hal ini bias dipahami dari ayat yang pertama kali turun, yakni:

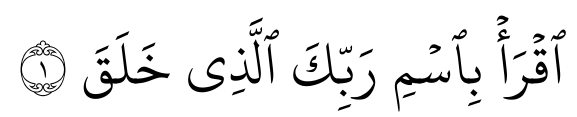

Artinya: "bacalah dengan (menyebut) nama Tuhanmu yang Menciptakan,"

Vol. 10 No. 1, Desember 2017

Madrasah homepage: http://ejournal.uin-malang.ac.id/index.php/madrasah/index 


\section{MADRASAH}

Jurnal Pendidikan dan Pembelajaran Dasar

p ISSN: 1979-5599 | e ISSN: 2502-194X

P a g e

Ayat ini berarti manusia telah diperintahkan untuk membaca guna memperoleh berbagai pemikiran dan pemahaman. Tetapi segala pemikirannya itu tidak boleh lepas dari Aqidah Islam, karena iqra' haruslah dengan bismi rabbika, yaitu tetap berdasarkan iman kepada Allah, yang merupakan asas aqidah Islam. Tujuan Pendidikan Agama Islam adalah sebagai usaha untuk mengarahkan dan membimbing manusia dalam hal ini peserta didik agar mereka mampu menjadi manusia yang beriman dan bertaqwa kepada Allah SWT, serta meningkatkan pemahaman, penghayatan, dan pengamalan mengenai Agama Islam, sehingga menjadi manusia Muslim, berakhlak mulia dalam kehidupan baik secara pribadi, bermasyarakat, berbangsa dan menjadi insan yang beriman hingga mati dalam keadaan Islam, sebagaimana Firman Allah Swt dalam Al-Qur'an surat Ali Imran ayat 102 .

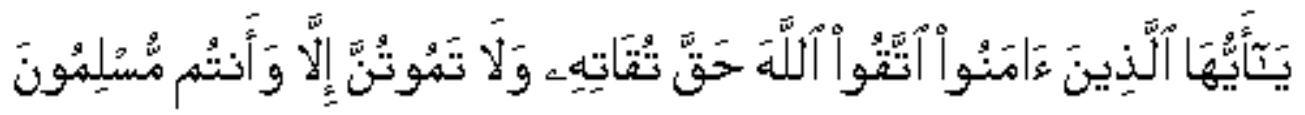

Artinya: "Hai orang-orang yang beriman, bertakwalah kepada Allah sebenar-benar takwa kepada-Nya; dan janganlah sekali-kali kamu mati melainkan dalam keadaan beragama Islam."

Mengingat begitu pentingnya kedudukan aqidah, tujuan yang paling esensial dari pendidikan Islam adalah menanamkan aqidah secara benar ke dalam diri anak didik. Kata integrasi berarti pencampuran, pengkombinasian, dan perpaduan. Integrasi biasanya dilakukan terhadap dua hal atau lebih, dan masingmasing dapat mengisi. Dalam melaksanakan integrasi, asas korelasi dan harmonisasi adalah asas yang harus dipenuhi. Pencampuran atau pengkombinasian beberapa mata pelajaran dalam sebuah tema atau pembelajaran harus tetap memperhatikan segi korelasi dan harmonisasinya (Susan M. Drake, 1998:46-47). Dengan demikian, perspektif yang beragam, pengalaman yang bermacam-macam, pendekatan dan bidang keilmuan yang variatif harus tetap memiliki keterkaitan antara satu sarna lain dan tidak saling bertentangan, agar dapat saling mengisi dan melengkapi. Pada tataran praktis, penciptaan korelasi dan harmonisasi dalam kurikulum integratif sangat ditentukan kemampuan melakukan eksplorasi (terutama guru) terhadap berbagai isu penting yang sedang berkembang, kemampuan melihat sebuah topik dari sudut pandang yang luas, dan menghindari pengulangan-pengulangan yang membingungkan.

Secara implementatif dalam wilayah pembelajaran, integrasi keilmuan selayaknya mencakup beberapa ranah, seperti filosofis, ranah materi, ranah metodologi, dan ranah strategi (Pokja Akademik UIN Sunan Kalijaga, 2006). Ranah filosofis dalam pembelajaran berarti bahwa setiap mata pelajaran harus diberi nilai fundamental eksistensial dalam kaitannya dengan disiplin ilmu lainnya. Pada ranah materi, pembelajaran integratif ditandai dengan pengintegrasian materi satu disiplin ilmu dengan lainnya untuk saling melenkapi dan menguatkan. Integrasi

Vol. 10 No. 1, Desember 2017

Madrasah homepage: http://ejournal.uin-malang.ac.id/index.php/madrasah/index 
pada ranah metodologi pembelajaran mengharuskan penggunaan berbagai pendekatan keilmuan, sedangkan pada ranah strategi pembelajaran integratif ditunjukkan dengan penerapan strategi pembelajaran yang variatif dengan penekanan yang besar terhadap prinsip pembelajaran aktif.

Dari sisi epistemologi keilmuan, terdapat perbedaan mendasar antara sains dan agama, khususnya Islam. Banyak ahli mengatakan bahwa sains dan agama berbeda dalam metodologi ketika keduanya mencoba untuk menj elaskan kebenaran. Metode agama umumnya bersifat subyektif, tergantung pada intuisi/pengalaman pribadi dan otoritas nabi/kitab suci. Sedangkan sains bersifat obyektif, yang lebih mengandalkan observasi dan interpretasi terhadap fenomena yang teramati dan dapat diverifikasi. Secara rinci, Barbour dengan mengutip pendapat Longdon Gilkey membuat pemetaan dalam penelitian sains dan agama sebagai berikut: (1) Sains mencoba menjelaskan data yang bersifat obyektif, publik dan dapat diulang. Agama menjelaskan hal-hal yang berhubungan dengan eksistensi tatanan dan keindahan dunia serta pengalaman kehidupan dakhil (seperti rasa bersalah, kecemasan dan ketidakberartian, pada saru sisi, dan pemanfaatan, kepercayaan dan keseluruhan, pada sisi yang lain). (2) Sains mengajukan pertanyaan "bagaimana" yang obyektif, sedangkan agama mengaj ukan pertanyaan "mengapa" tentang makna dan tujuan serta asal mula dan takdir berakhir. (3) Otoritas dalam sains adalah koherensi, logis dan kesesuaian eksperimental. Sedangkan otoritas terteinggi dalam agama adalah Tuhan dan wahyu yang diterima oleh orang-orang terpilih yang memperoleh pencerahan dan wawasan rohani dan diyakini melalui pengalaman personal. (4) Sains melakukan prediksi kuantitatif yang dapat diuji secara eksperimental. Sedangkan agama harus menggunakan bahwa simbolis dan analogis karena Tuhan bersifat transenden (Ian G. Barbour, 1971:67).

Berdasarkan paparan di atas, pada dasarnya tidak ada perbedaan yang ekstrim antara sains dan agama. Keduanya saling terikat dan saling melengkapi. Dengan adanya integrasi sains dan agama khususnya dalam pendidikan Islam justru membawa manfaat yang besar, yakni mengenalkan dan mengajarkan siswa tentang Tuhan melalui pengetahuan umum yang mereka pelajari. Perkembangan zaman menyebabkan segaka sesuatu terasa kompleks. Demikian pula dengan pembelajaran. Semakin derasnya arus informasi menyebabkan model pembelajaran yang digunakan rupanya tidak cukup jika hanya mengandalkan salah satu keilmuan. Untuk itu perlu adanya integrasi di antara mata pelajaran yang ada dengan nilai-nilai pendidikan karakter, termasuk karakter religius.

Atas dasar pemikiran tersebut, perlu kiranya menggabungkan, mengkombinasikan mata pelajaran agama khususnya PAI dan Budi Pekerti yang sesuai dengan mata pelajaran umum yang diikat dalam satu tema. Pengkombinasian tersebut diwujudkan dalam penyusunan buku ajar dengan menggunakan pendekatan tematik integratif yang mengakomodir semua mata pelajaran termasuk PAI dan Budi Pekerti. Integrasi antara buku ajar tematik dengan muatan PAI dan Budi pekerti dapat dilakukan dengan cara memetakan dan memilah muatan PAI dan Budi Pekerti sesuai dengan kompetensi dan tema yang

Vol. 10 No. 1, Desember 2017

Madrasah homepage: http://ejournal.uin-malang.ac.id/index.php/madrasah/index 


\section{MADRASAH}

Jurnal Pendidikan dan Pembelajaran Dasar

p ISSN: 1979-5599 | e ISSN: 2502-194X

ada di buku ajar tematik. Muatan PAI dan Budi Pekerti yang sesuai dengan kompetensi atau indikator pada tema dikombinasikan dalam satu tema dalam buku ajar. Muatan PAI dan Budi Pekerti bisa dijabarkan dalam bentuk materi atau kegiatan pembelajaran diselaraskan dengan tema yang sedang dibahas. Kaitannya dengan menanamkan karakter religius, maka indikator-indikator adri karakter religius sebagaimana yang dipaparkan sebelumnya dapat dimplementasikan dalam bentuk materi atau kegiatan pembelajaran dalam satu buku ajar yang sama. Gambaran tersebut dapat dilihat sebagaimana contoh gambar berikut ini, di mana kompetensi-kompetensi mata pelajaran dipadukan dan dikemas dalam satu buku ajar.
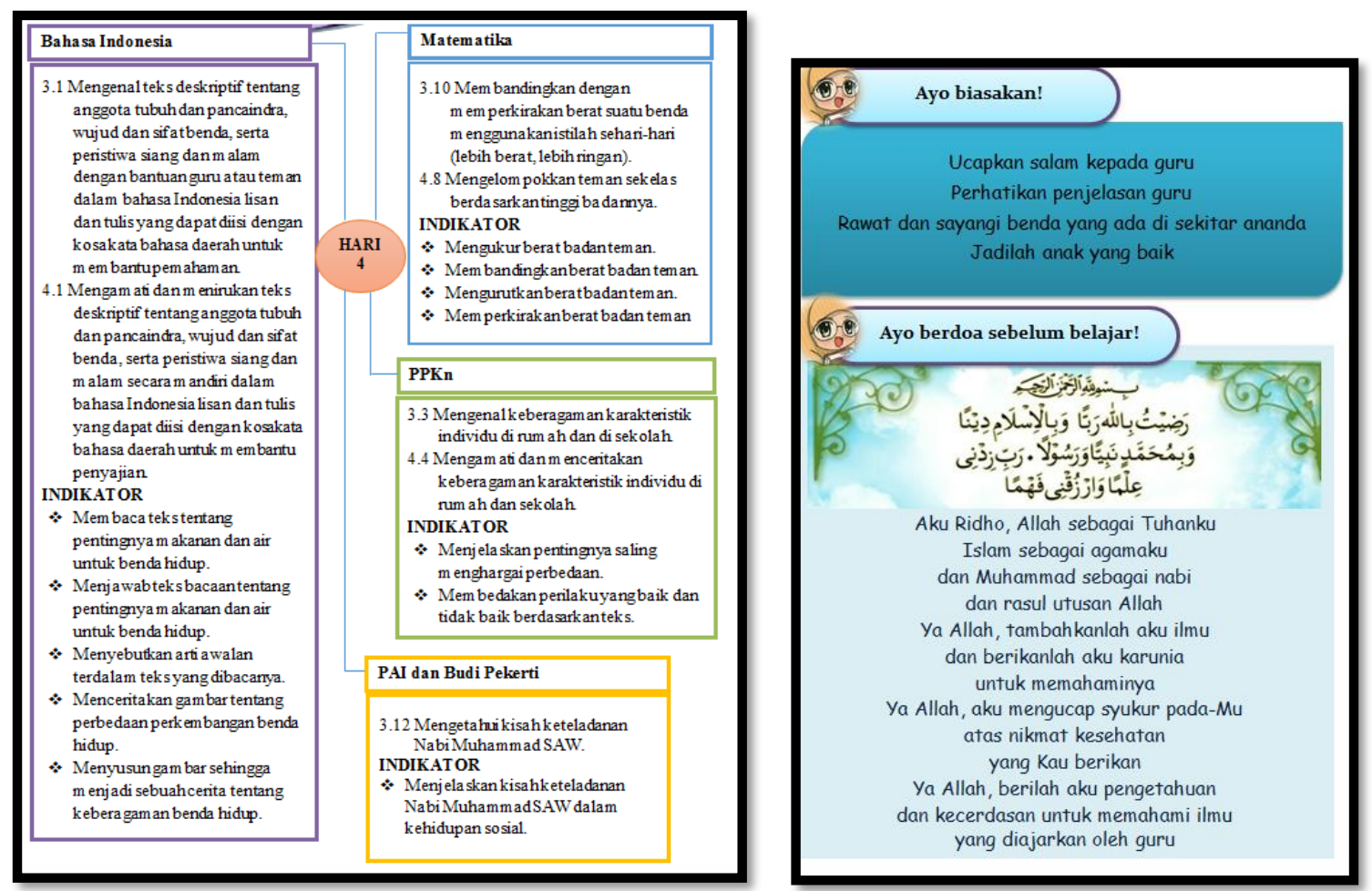

Vol. 10 No. 1, Desember 2017

Madrasah homepage: http://ejournal.uin-malang.ac.id/index.php/madrasah/index 

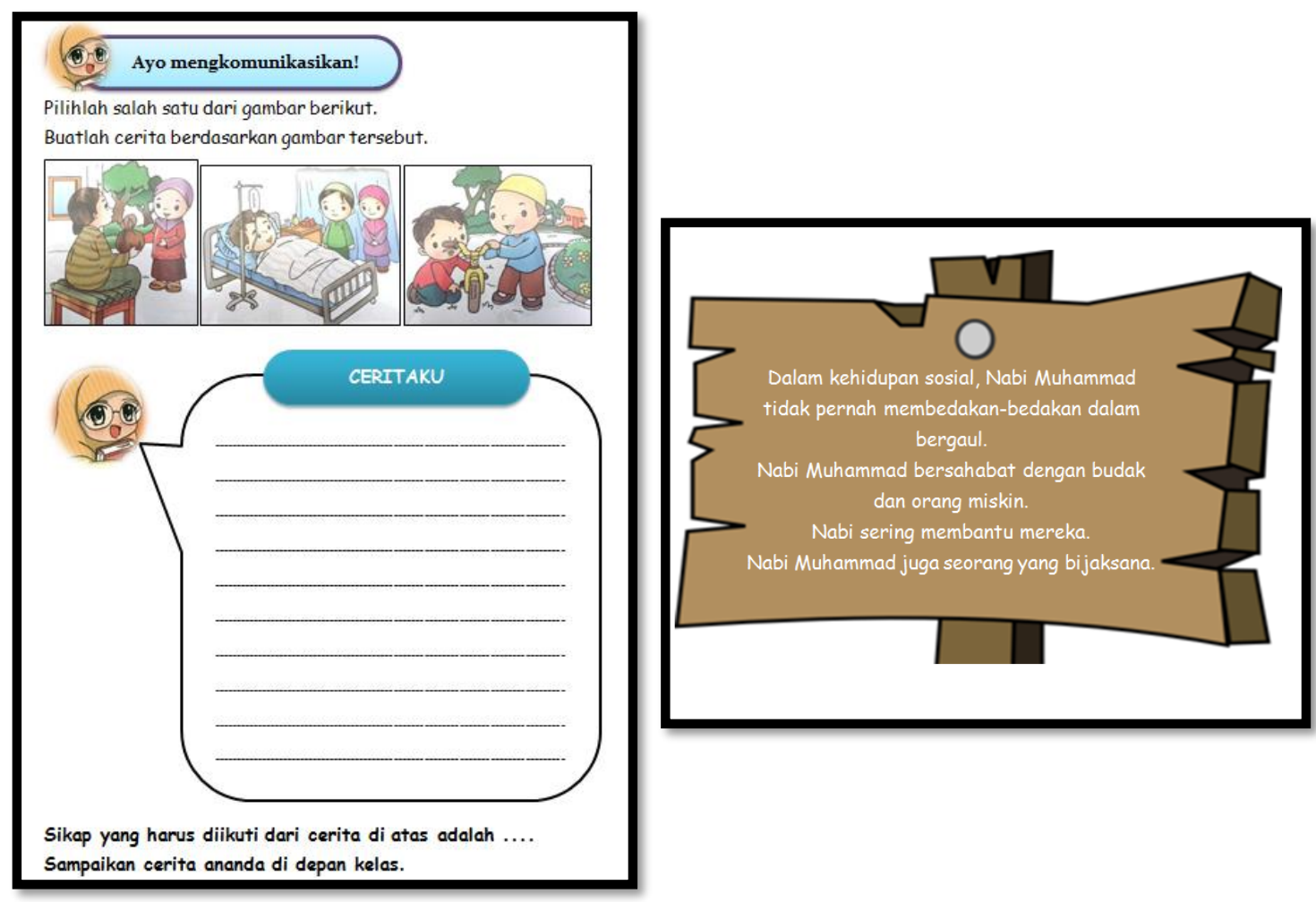

\section{Buku Ajar Tematik Terintegrasi PAI dan Budi Pekerti Sebagai Sarana Menanamkan Karakter Religius}

Keberhasilan seorang guru dalam melaksanakan pembelajaran tematik tergantung pada wawasan, pengetahuan, pemahaman, dan tingkat kreativitasnya dalam mengelola bahan ajar. Semakin lengkap bahan yang terkumpulkan dan semakin luas wawasan serta pemahaman guru terhadap materi tersebut, cenderung akan semakin baik pembelajaran yang dilaksanakan (Trianto, 2013: 180). Mengacu model pembelajaran tematik, dalam melaksanakan penanaman karakter agar maksimal, guru perlu memperhatikan hal-ha sebagai berikut. Pertama, dimungkinkan terjadi penggabungan kompetensi dasar lintas semester. Penggabungan ini dilakukan untuk lebih mnegefektifkan waktu yang ada sekaligus untuk memberi waktu yang lebih luas kepada siswa dalam memahami kompetensi dasar yang memiliki keserupaan. Kedua, kegiatan inti ditekankan kepada kemampuan kognisi dan mempraktikkan nilai-nilai afektif pendidika karakter.

Pengaruh utama kegiatan belajar mengajar yang berorientasi kepada kognisi mempunyai maksud agar siswa semakin tajam dan analitik dalam mengupas berbagai soal yang diberikan. Sementara penajaman nilai-nilai afektif ditujukan agar siswa memiliki kepekaan sekaligus pembiasaan terhadap norma, agama, dan budaya sehingga menjadi kepribadian sehari-harinya. Ketiga, tema-tema yang dipilih disesuaikan dengan karakteristik siswa, minat, lingkungan, dan daerah setempat. Hal ini dilakukan agar pembelajaran yang diselenggarakan menjadi menyenangkan sekaligus mendorong isswa untuk lebih leluasa melakukan interaksi antara siswa dengan guru dan lingkungannya. Keempat, beberapa aspek

Vol. 10 No. 1, Desember 2017

Madrasah homepage: http://ejournal.uin-malang.ac.id/index.php/madrasah/index 


\section{MADRASAH}

Jurnal Pendidikan dan Pembelajaran Dasar

p ISSN: 1979-5599 | e ISSN: 2502-194X

P a g e | 31

pembelajaran tidak semuanya dapat dipadukan (Departemen Agama RI, 2009: 180). Hal ini dilakukan agar kegiatan belajar mengajar yang dilangsungkan benar-benar mampu menitikberatkan kepada penguasaan target kompetensi dan karakter secara bersamaan.

Pelaksanaan pembelajaran dan penanaman karakter dilakukan seperti tahapan pembelajaran biasanya, yakni kegiatan pendahuluan atau pembukaan, kegiatan inti, dan kegiatan penutup. Kegiatan pendahuluan dilakukan untuk menciptakan suasana awal pembelajaran melalui penggalian pengetahuan atau pengalaman siswa. kegiatan inti difokuskan pada kegiatan yang bertujuan mengembangkan kemampuan penghayatan keimanan, pemahaman, dan pengamalan. Kegiatan penutup berupa menyimpulkan atau mengungkapkan hasil pembelajaran yang telah dilaksanakan. Untuk mendorong agar pemaknaan pendidikan karakter dapat diterjemahkan dalam kehidupan sehari-hari, perlu adanya kontekstualisasi terhadap setiap materi dan makna mata pelajaran yang diperoleh siswa. hal ini dilakukan agar manfaat dari hasil pembelajaran dapat dirasakan di tengah-tengah masyarakat. Kontekstualisasi pembelajaran akan mendekatkan siswa terhadap apa yang dipelajarinya untuk didekatkan kepada kehidupannya.

Penanaman karakter di sekolah dikembangkan dari elemen pembelajaran yang terikat satu sama lain. Tafsir menjelaskan bahwa penanaman karakter yang mendasarkan diri dari nilai-nilai luhur agama, kebangsaan, dan kebudayaan merupakan suatu kegiatan pembelajaran yang di dalamnya mengandung aspek tujuan, keurikulum, guru, metode pendekatan, sarana prasarana, lingkungan, administrasi, dan sebagainya yang antara satu dan lainnya saling berkaitan dan membentuk suatu sistem terpadu (Ahmad Tafsir, 1994:47). Oleh karena itu, pada era modern saai ini, sudah semestinya paradigma pembelajaran dan pendidikan karakter dikaitkan dengan berbagai mata pelajaran yang ada. Sebab pada dasarnya, efektivitas sebuah mata pelajaran yang bertujuan membentuk kompetensi siswa yang utuh akan terbentuk manakala mata pelajaran yang diberikan terintegrasi satu sama lain. Model pembelajaran demikian akan menimbulkan dampak berganda (Multiplier effect) kepada peningkatan kompetensi siswa.

Penanaman karakter dapat diimplementasikan melalui beberapa strategi dan pendekatan yang meliputi: 1) pengintegrasian nilai dan etika pada setiap mata pelajaran; 2) internalisasi nilai positif yang ditanamkan oleh semua warga sekolah (kepala sekolah, guru, dan orangtua); 3) pembiasaan dan latihan. Dengan komitmen dan dukungan dari berbagai pihak, institusi sekolah dapat mengimplementasikan kegiatan-kegiatan positif seperti salam, senyum, dan sapa setiap hari saat anak datang dan pulang sekolah; 4) pemberian contoh atau teladan; 5) penciptaan suasana berkarakter di sekolah; 6) pembudayaan (Agus Zaenul Fitri, 2012:46). Pendidikan karakter tidak bisa berdiri sendiri, melainkan merupakan suatu nilai yang menjadi satu kesatuan dengan setiap mata pelajaran yang ada di sekolah. Proses penanaman karakter juga tidak bisa dalam waktu yang singkat,

Vol. 10 No. 1, Desember 2017

Madrasah homepage: http://ejournal.uin-malang.ac.id/index.php/madrasah/index 
tetapi memerlukan sebuah proses yang kontinu dan konsisten dari hari ke hari. Oleh sebab itu, hasilnya pun tidak dapat dilihat secara instan.

Untuk membangun budaya dalam rangka membentuk karakter pada siswa, langkah yang perlu dilakukan adalah menciptakan suasana yang berkarakter (penuh dengan nilai-nilai) terlebih dahulu. Penciptaan suasana berkarakter sangat dipengaruhi oleh situasi dan kondisi tempat model itu akan diterapkan beserta penerapan nilai yang mendasarinya. Pertama, penciptaan budaya berkarakter yang bersifat vertikal atau ilahiah. Kegiatan ini dapat diwujudkan dalam bentuk hubungan dengan Allah SWT, Tuhan Yang Maha Esa melalui peningkatan secara kuantitas maupun kualitas kegiatan-kegiatan keagamaan di sekolah yang bersifat ubudiyah, seperti shalat berjamaah, puasa senin dan kamis, membaca Al-Qur'an, doa bersama, dan lain sebagainya. Kedua, penciptaan budaya berkarakter yang bersifat horizontal atau insaniah. Yaitu lebih mendudukkan sekolah sebagai institusi sosial, yang apabila dilihat dari struktur hubungan antarmanusianya, dapat diklasifikasikan ke dalam tiga hubungan, yaitu: 1) hubungan atasanbawahan; 2) hubungan profesional; 3) hubungan sederajat atau sukarela yang didasarkan pada nilai-nilai positif, seperti persaudaraan, kedermawanan, kejujuran, saling menghormati, dan sebagainya. Pengembangan pendidikan dalam mewujudkan budaya berkarakter di sekolah yang bersifat horizontal tersebut dapat dilakukan melalui pendekatan pembiasaan, keteladanan, dan pendekatan persuasif atau mengajak kepada warga sekolah dengan cara yang halus, dengan memberikan alasan dan prospek baik yang bisa meyakinkan mereka.

Strategi penanaman karakter dapat dilakukan melalui empat pendekatan berikut. Pertama, pendekatan instruktif-struktural, yaitu strategi penanaman karakter di sekolah sudah menjadi komitmen dan kebijakan yang mendukung terhadap berbagai kegiatan berkarakter di sekolah beserta berbagai sarana dan prasarana pendukungnya. Kedua, pendekatan formal-kurikuler, yaitu strategi penanaman karakter di sekolah melalui pengintegrasian dan pengoptimalan kegiatan belajar mengajar di semua mata pelajaran dan karakter yang dikembangkan. Dengan cara ini, guru mempunyai peran yang lebih dominan dalam menanamkan karakter, karena terintegrasi dalam setiap mata pelajaran. Ketiga, pendekatan mekanik-fragmented, yaitu strategi penanaman karakter di sekolah didasari oleh pemahaman bahwa kehidupan terdiri atas berbagai aspek dan pendidikan dipandang sebagai penanaman dan pengembangan seperangkat nilai kehidupan yang masing-masing bergerak dan berjalan menurut fungsinya.

Secara lebih gamblang, strategi penanaman karakter melalui pengintegrasian dapat dilihat dalam berbagai bentuk, yaitu: 1) integrasi ke dalam mata pelajaran; 2) integrasi melalui pembelajaran tematik; 3) integrasi melalui penciptaan suasana berkarakter dan pembiasaan; 4) integrasi melalui kegiatan ekstrakurikuler; 5) integrasi antara program pendidikan sekolah, keluarga, dan masyarakat. Berdasarkan paparan tersebut, jelas bahwa penanaman karakter, termasuk karakter religius bisa dilakukan melalui pengintegrasian dengan pembelajaran tematik, sebagaimana yang ada pada buku ajar tematik terintegrasi PAI dan Budi Pekerti. Buku ajar ini tidak hanya memuat PAI dan Budi Pekerti

Vol. 10 No. 1, Desember 2017

Madrasah homepage: http://ejournal.uin-malang.ac.id/index.php/madrasah/index 


\section{MADRASAH}

Jurnal Pendidikan dan Pembelajaran Dasar

p ISSN: 1979-5599 | e ISSN: 2502-194X

P a g e

sebagai sebuah mata pelajaran, tetapi juga sarana menanamkan karakter religius. Buku ajar digunakan setiap hari oleh siswa dan menjadi sumber rujukan utama dalam pembelajaran, sehingga seiring berjalannya waktu mereka akan terbiasa melakukan rutinitas kegiatan pembelajaran yang secara instrinsik memuat karakter religius.

Melalui bimbingan guru atau orangtua di rumah, siswa bisa melakukan kegiatan-kegiatan yang diarahkan dalam buku ajar tematik terintegrasi PAI dan Budi Pekerti dalam rangka penanaman karakter religius, misal melalui pembiasaan salam, berdoa, menilai diri dalam pelaksanaan ibadah, dan lain sebagainya. Jika orangtua dan guru mampu bekerjasama dengan baik dalam pembiasaan dan komitmen untuk menciptakan suasana yang mendukung, maka tujuan yang diharapkan akan dapat terwujud, yakni tertanamnya karakter religius pada diri siswa. namun yang perlu digaris-bawahi adalah, tidak ada proses yang instan dalam penanaman karakter, semua perlu pembiasaan melalui rutinitas kegiatan dan arahan sebagaimana yang ada pada buku ajar tematik terintegrasi PAI dan Budi Pekerti. Karena bagi siswa buku ajar merupakan salah satu kitab yang mereka percayai dan pedomani, maka buku ajar tematik integratif yang terintegrasi dengan PAI dan Budi Pekerti mempunyai peran penting sekaligus merupakan salah satu trobosan atau inovasi dalam rangka menanamkan karakter religius pada siswa.

\section{PENUTUP}

Proses penanaman karakter religius pada siswa akan berhasil apabila guru mampu melakukan inovasi atau pengembangan pembelajaran dalam meningkatkan kualitas pembelajaran itu sendiri. Salah satu upaya yang bisa ditempuh oleh seorang guru adalah dengan memadukan buku ajar tematik yang tersedia dengan muatan PAI dan Budi Pekerti. Buku ajar yang baik tentunya dapat menunjang tercapainya tujuan atau target pembelajaran. Muatan PAI dan Budi pekerti dalam buku ajar akan mengenalkan dan mengembalikan siswa pada agamanya. Pengetahuan yang mereka dapatkan akan utuh dan menyeluruh, ketika siswa mempelajari materi yang bersifat umum, mereka juga akan mendapat materi agama karena keduanya sudah dipadukan dalam satu konsep pembelajaran. Melalui buku ajar tematik yang terintegrasi dengan PAI dan Budi Pekerti akan membuat siswa lebih dekat dengan agama dan terbiasa mempelajari suatu ilmu secara utuh baik dari sisi agama maupun keilmuan umumnya. Membiasakan siswa dekat dengan agamanya akan meningkatkan religuisitasnya. Sehingga dengan demikian karakter religius pada diri siswa akan terbentuk. Melalui buku ajar ini siswa tidak hanya mengenal agamanya saja tetapi juga paham dan mampu menerapkan dalam kehidupan sehari-hari.

Vol. 10 No. 1, Desember 2017

Madrasah homepage: http://ejournal.uin-malang.ac.id/index.php/madrasah/index 


\section{REFERENSI}

Akbar, Sa'dun. (2013). Instrumen Perangkat Pembelajaran. Bandung: PT Remaja Rosdakarya.

Astuti, Dwi Yuliyanti. (1974). Hubungan Antara Religiusitas dengan Gaya Penjelasan pada Mahasiswa Muslim. Jurnal Psikologi No. 3 Th. II

B.P. Sitepu. (2012). Penulisan Buku Teks Pelajaran. Bandung: PT Remaja Rosdakarya

Barbour, Ian G. 1971. Issues in Science an Religion. New York: Harper and Row Publisher.

Departemen Agama RI. (2009). Pedoman Penyusunan Pembelajaran Tematik Pendidikan Agama Islam Sekolah Dasar (SD). Jakarta: Departemen Agama

Drake, Susan M. (1998). Creating Integrated Curriculum Proven Ways to Increase Student Learning. California: Corwin Press

Echols, John. (2005). Kamus Populer. Jakarta: Rineka Cipta Media

F.J. Monks, A.M.P. Knoers. (2002). “Psikologi Perkembangan: Pengantar dalam Berbagai Bagiannya. Yogyakarta; Gajah Mada University Press.

Fitri, Agus Zaenul. (2012). Reinventing Human Character: Pendidikan Karakter Berbasis Nilai dan Etika di Sekolah. Jogjakarta: Ar-Ruzz Media

Mu'in, Fatchul. (2011). Pendidikan Karakter Konstruksi Teoretis dan Praktik Urgensi Pendidikan Progresif dan Revitalisasi Peran Guru dan Orangtua. Yogyakarta: ArRuzz Media

Muhaimin. (1996). Strategi Belajar Mengajar. Surabaya: Citra Media

Musfah. (2011). Pendidikan Karakter: Sebuah Tawaran Model Pendidikan HolistikIntegralistik. Jakarta: Prenada Media

Pokja Akademik UIN Sunan Kalijaga. (2006). Kerangka Dasar Keilmuan dan Pengembangan Kurikulum. Yogyakarta: UIN Sunan Kalijaga

Supiana. (2011). Mozaik Pemikiran Islam: Bunga Serampai Pemikiran Pendidikan Indonesia. Jakarta: Ditjen Dikti

Tafsir, Ahmad. (1994). Ilmu Pendidikan dalam Perspektif Islam, Cet. II (Bandung: Rosda Karya

Tarigan. (1986). Telaah Buku Teks Bahasa Indonesia. Bandung: Angkasa

Trianto. (2013). Desain Pengembangan Pembelajaran Tematik bagi Anak Usia Dini TK/RA dan Anak Usia Awal SD/MI. Jakarta: Kencana Prenada Media Group 